\title{
ANALISIS PUTUSAN PAILIT NOMOR: 02/PAILIT/2009/PN.NIAGA.SMG TERHADAP UNDANG-UNDANG NOMOR 37 TAHUN 2004 TENTANG KEPAILITAN DAN PENUNDAAN KEWAJIBAN PEMBAYARAN UTANG
}

\author{
Fransman Ricardo Tamba \\ Jaksa di Cabang Kejaksaan Negeri Tana Toraja di Rantepao \\ Email: fransmantamba@gmail.com
}

\begin{abstract}
Abstrak
Perseroan Terbatas memiliki hak melakukan perbuatan hukum didalam pengadilan. Salah satunya adalah mengajuakn permohonan pailit terhadap dirinya sendiri kepada Pengadilan Niaga untuk masalah insolvensi dan kesulitan kondisi keuangan. Undang-Undang Nomor 37 Tahun 2004 Tentang Kepailitan dan Penundaan Kewajiban Pembayaran Utang memberikan solusi. Terbukti dengan adanya putusan pailit nomor : 02/Pailit/2009/PN.Niaga.Smg. Peneliti membahas mengenai dasar permohonan pailit yang diajukan oleh Pemohon pailit dan pertimbangan yang diberikan oleh majelis hakim dalam memeriksa dan memutus perkara pailit nomor : 02/Pailit/2009/PN.Niaga.Smg. Peneliti menggunakan metode penelitian kualitatif dengan metode yuridis normatif dan metode pendekatan analitis (analytical approach). Teknik pengumpulan data yang digunakan, yaitu studi dokumen dan wawancara. Sumber data yang digunakan adalah data primer dan data sekunder. Keabsahan data yang dipergunakan dalam penelitian ini menggunakan triangulasi data yang memanfaatkan penggunaan sumber. Hakim yang memeriksa dan mengadili perkara pailit nomor : 02/Pailit/2009/PN.Niaga.Smg menerima dan mengabulkan permohonan Pemohon Pailit berdasarkan Pasal 2 Ayat (1) dan Pasal 8 Ayat (4) Undang-Undang Nomor 37 Tahun 2004 Tentang Kepailitan dan Penundaan Kewajiban Pembayaran Utang. Namun, Undang-Undang Nomor 37 Tahun 2004 Tentang Kepailitan Dan Penundaan Kewajiban Pembayaran Utang tidak memperinci masalah syarat perimbangan anatar aktiva dan pasiva, keadaan insolvensi dan kesulitan kondisi keuangan yang membuat dapat dimintakan permohonan pailit, serta tidak memperinci alasan dan mekanisme permohonan pailit terhadap dirinya sendiri, permohonan pailit oleh Kreditor, dan permohonan oleh Pihak ke tiga.
\end{abstract}

Kata Kunci: Pailit, Pengadilan, Permohonan, Putusan. 


\section{PENDAHULUAN}

Perseroan Terbatas memiliki hak dan kewajiban layaknya orang-perorangan yang dapat melakukan perbuatan hukum sendiri, baik didalam maupun diluar pengadilan. bentuk perbuatan hukum yang dapat dilakukan Perseroan Terbatas di dalam pengadilan adalah mengajukan permohonan pailit kepada pengadilan niaga guna menyelesaikan masalah insolvensi (insolvency) yang dihadapi oleh Perseroan Terbatas.

Insolvensi (insolvency) merupakan keadaan dimana Perseroan Terbatas sebagai Debitor tidak lagi memiliki kemampuan untuk menjalankan kewajibannya pada Kreditor. Insolvensi (insolvency) merupakan kejadian yang terjadi sebagai akibat Perseroan Terbatas mengalami kesulitan kondisi keuangan (financial distrees). Kesulitan kondisi keuangan (financial distrees) merupakan hasil dari tindakan yang diputuskan untuk diambil oleh Perseroan Terbatas sebelumnya, sehingga menimbulkan ketidakpastian dan mengarah pada suatu hal yang bersifat negatif, yaitu kebangkrutan.

Untuk mengatasi masalah kebangkrutanya kepada Kreditor dan pihak ketiga, undang-undang memberikan solusi untuk menggunakan Undang-Undang No. 37 Tahun 2004 Tentang Kepailitan dan Penundaan Kewajiban Pembayaran Utang, yang mana kepailitan adalah sita umum atas semua kekayaan Debitor Pailit yang pengurusan dan pemberesannya dilakukan oleh Kurator di bawah pengawasan Hakim Pengawas. Selain kepailitan, undang-undang memberikan solusi untuk menggunakan upaya permohonan Penundaan Kewajiban Pembayaran Utang (surseance van betaling) yang disingkat dengan PKPU.

Putusan pailit Nomor : 02/Pailit/2009/PN.Niaga.Smg, yang menyatakan bahwa Debitor sebagai pihak yang mengajukan sendiri permohonan pailit guna menyelesaikan masalah insolvensi (insolvency) yang sedang dihadapinya dengan para Kreditor. Putusan pailit nomor : 02/Pailit/2009/PN.Niaga.Smg juga memberikan gambaran mengenai hal apa yang didasarkan oleh Debitor sebagai pemohon dalam mengajukan permohonan pailit terhadap dirinya sendiri dan juga mengenai dasar pertimbangan yang diberikan oleh majelis hakim dalam memutus 
permohonan pailit terhadap Debitor sebagai pemohon pailit, serta akibat hukum yang timbul bagi Debitor guna memecahkan masalah insolvensi (insolvency) yang dihadapinya. Selain itu, dalam putusan tersebut tidak ada upaya permohonan Penundaan Kewajiban Pembayaran Utang (surseance van betaling) yang disingkat dengan PKPU.

Berdasarkan paparan di atas maka perlu untuk dianalisis apakah dasar permohonan pailit yang diajukan oleh Pemohon pailit dalam putusan pailit nomor : 02/Pailit/2009/PN.Niaga.Smg telah sesuai dengan Undang-Undang Nomor 37 Tahun 2004 Tentang Kepailitan dan Penundaan Kewajiban Pembayaran Utang. Selain itu apakah pertimbangan yang diberikan oleh majelis hakim dalam putusan pailit nomor : 02/Pailit/2009/PN.Niaga.Smg telah sesuai dengan Undang-Undang Nomor 37 Tahun 2004 Tentang Kepailitan dan Penundaan Kewajiban Pembayaran Utang.

\section{METODE PENELITIAN}

Penelitian ini menggunakan jenis penelitian kualitatif. Moleong berpendapat metode penelitian kualitatif berusaha menjelaskan suatu gejala dengan data deskriptif yang wujudnya adalah kata-kata tertulis maupun lisan dari suatu objek yang diteliti (Moleong 2013:4). Peneliti menggunakan penelitian yuridis normatif dengan metode pendekatan analitis (analytical approach) yang bertujuan untuk menemukan kebenaran berdasarkan logika keilmuan hukum dari segi normatifnya. Menurut Johnny Ibrahim pendekatan analitis (analytical apprroach) merupakan pendekatan yang berusaha menemukan makna dari suatu undangundang yang dilihat dalam praktik dan putusan-putusan hakim. Hal tersebut dilakukan dengan dua metode pengujian, yaitu pengujian dalam hal memperoleh makna baru dalam undang-undang dan menguji istilah baru tersebut dalam praktik melalui analisi terhadap putusan hakim (Ibrahim 2008-310).

Lokasi yang dijadikan tempat penelitian oleh peneliti yaitu di Pengadilan Niaga Semarang, kantor Advokat Dan Legal Konsultan Wardana And Partners, Perpustakaan Pusat Universitas Negeri Semarang, Perpustakaan Fakultas Hukum 
Universitas Negeri Semarang, serta media elektronik dengan menggunakan media internet sebagai pendukungnya. Fokus masalah dalam penelitian ini adalah dasar permohonan pailit yang diajukan oleh Pemohon pailit dalam putusan pailit nomor : 02/Pailit/2009/PN.Niaga.Smg telah sesuai dengan Undang-Undang Nomor 37 Tahun 2004 Tentang Kepailitan dan Penundaan Kewajiban Pembayaran Utang dan Pertimbangan yang diberikan oleh majelis hakim dalam putusan pailit nomor : 02/Pailit/2009/PN.Niaga.Smg telah sesuai dengan Undang-Undang Nomor 37 Tahun 2004 Tentang Kepailitan dan Penundaan Kewajiban Pembayaran Utang.

Untuk mendukung proses penelitian yang dilakukan oleh peneliti, sumber data yang digunakan peneliti dalam melakukan penelitian ini, yaitu data primer dan data sekunder. Sumber bahan hukum primer ini berupa putusan pailit nomor: 02/Pailit/2009/PN.Niaga.Smg, catatan-catatan resmi atau risalah terkait putusan pailit nomor: 02/Pailit/2009/PN.Niaga.Smg, baik yang ada di Pengadilan Niaga Semarang maupun yang ada di kantor Advokat Dan Legal Konsultan Wardana And Partners, Undang-Undang Nomor 37 Tahun 2004 Tentang Kepailitan dan Penundaan Kewajiban Pembayaran Utang, Undang-Undang Nomor 40 Tahun 2007 Tentang Perseroan Terbatas, Undang-Undang Nomor 13 Tahun 2003 Tentang Ketenagakerjaan. Sedangkan data sekunder merupakan data berupa hasil wawancara dan publikasi tentang hukum yang bukan merupakan dokumen resmi berupa buku-buku yang berkaitan dengan hukum kepailitan, skripsi yang berkaitan dengan hukum kepailitan, tesis yang berkaitan dengan hukum kepailitan, desertasi yang berkaitan dengan hukum kepailitan dan jurnal-jurnal yang berkaitan dengan hukum kepailitan. Selain itu kamus-kamus hukum dan komentar-komentar atas putusan pengadilan juga merupakan bagian dari data sekunder yang digunakan oleh peneliti. Data sekunder itu merupakan dukungan data yang diperoleh langsung dari responden Prisma W. Sasmita, SH., MM., M.Hum. Merupakan advokat yang mewakili PT. Uniqwood Karya sebagai Pemohon Pailit dalam putusan pailit nomor: 02/Pailit/2009/PN.Niaga.Smg dan Arief Setiawan, SH., MH. Merupakan rekanan dari Prisma W. Sasmita, SH., MM., M.Hum, sekaligus kuasa dari PT. Uniqwood Karya setelah adanya putusan pailit nomor: 02/Pailit/2009/PN.Niaga.Smg. Sedangkan informan adalah Dr. Ifa 
Sudewi, SH., M.Hum. Merupakan wakil ketua Pengadilan Negeri Semarang hingga desember 2014, yang merupakan hakim dibidang kepailitan, Siti Jamzan, SH., MH. Merupakan hakim Pengadilan Negeri Semarang yang membidangi masalah kepailitan dan Dr. M. Hadi Shubhan, SH., MH., CN. Merupakan ahli hukum dari Universitas Airlangga Surabaya yang membidangi masalah kepailitan. Metode pengumpulan data yang digunakan, yaitu metode dokumen dan wawancara (interview).

Peneliti menggunakan teknik pemeriksaan data triangulasi yang memanfaatkan penggunaan sumber dengan cara membandingkan hasil wawancara dengan isi suatu dokumen yang berkaitan.

Langkah-langkah yang dilakukan oleh peneliti dalam melakukan analisi data, yaitu pertama-tama Peneliti sebelumnya memahami putusan pailit nomor : 02/Pailit/2009/PN.Niaga.Smg. Selanjtnya peneliti melakukan identifikasi masalah terhadap putusan pailit nomor : 02/Pailit/2009/PN.Niaga.Smg, dengan cara membandingkan putusan pailit nomor : 02/Pailit/2009/PN.Niaga.Smg dengan Undang-Undang Nomor 37 Tanun 2004 Tentang Kepailitan dan Penundaan Kewajiban Pembayaran Utang. Selanjtnya peneliti menentukan rumusan masalah dari prosesn identifikasi masalah putusan pailit nomor : 02/Pailit/2009/PN.Niaga.Smg. Selanjtnya peneliti berusaha membaca dan memahami Undang-Undang Nomor 37 Tahun 2004 Tentang Kepailitan dan Penundaan Kewajiban Pembayaran Utang, Undang-Undang Nomor 40 Tahun 2007 Tentang Perseroan Terbatas, Undang-Undang Nomor 13 Tahun 2003 Tentang Ketenagakerjaan, buku-buku hukum, skripsi hukum, tesis hukum, desertasi hukum dan jurnal-jurnal hukum. Selanjtnya peneliti melakukan wawancara dengan responden dan mengumpulkan semua hasil wawancara. Selanjtnya peneliti melakukan wancara dengan informan dan mengumpulkan semua hasil wawancara. Selanjtnya peneliti melakukan analisis terhadap putusan pailit nomor : 02/Pailit/2009/PN.Niaga.Smg, yang dilihat dari sudut pandang Undang-Undang Nomor 37 Tahun 2004 Tentang Kepailitan dan Penundaan Kewajiban Pembayaran Utang, Undang-Undang Nomor 40 Tahun 2007 Tentang Perseroan Terbatas, Undang-Undang Nomor 13 Tahun 2003 Tentang 
Ketenagakerjaan, buku-buku hukum, skripsi hukum, tesis hukum, desertasi hukum dan jurnal-jurnal hukum serta hasil wawancara terhadap responden dan informan. Akhirnya peneliti memperoleh simpulan dan memberikan saran.

\section{HASIL PENELITIAN DAN PEMBAHASAN}

Dasar Permohonan Pailit Yang Diajukan Oleh Pemohon Pailit Dalam Putusan Pailit Nomor : 02/Pailit/2009/PN.Niaga.Smg telah sesuai dengan Undang-Undang Nomor 37 Tahun 2004 Tentang Kepailitan dan Penundaan Kewajiban Pembayaran Utang

PT. Uniqwood Karya merupakan suatu Perseroan Terbatas yang didirikan menurut Akta Pendirian No. 33 tanggal 11 agustus 1990 yang dibuat oleh Silvia Veronika, SH dan telah mendapat status badan hukum dengan pengesahan Menteri Hukum dan Perundang-undangan Nomor : C.2-1144.ht.0I.0I.Th.1991 tanggal 25 april 1991. PT. Uniqwood Karya bergerak di bidang industri kayu lapis laminasi, dan decorative plywood dan memiliki 41 karyawan untuk mendukung produksinya.

Melalui surat permohonan tertanggal 19 Januari 2009, PT. Uniqwood Karya mengajukan permohonan pailit di Kepaniteraan Pengadilan Niaga pada Pengadilan Negeri Semarang, dalam Register No. 02/Pailit/2009/PN.Niaga.Smg. Permohonan tersebut diajukan dan wakili oleh seorang advokat bernama Prisma W. Sasmita, SH, MM, M.HUM, berdasarkan Surat Kuasa Khusus tertanggal 3 Januari 2009.

Pemohon Pailit menjelaskan bahwa beberapa tahun terakhir pesanan terhadap hasil produksi mengalami penurunan dan usaha mengalami kerugian. Pemohon Pilit berusaha bertahan untuk aktivitas sehari-hari dengan menggunakan dana pinjaman dari beberapa Kreditor. Setelah mempertimbangakan kondisi keuangan dari Pemohon Pailit yang semakin buruk dan sudah tidak memungkinkan lagi untuk melanjutkan aktivitas Perseroan Terbatas, maka Pemohon Pailit mengajukan permohonan pailit a quo secara sukarela. Permohonan pailit tersebut telah disetujui dalam Rapat Umum Pemegang Saham Luar Biasa sebagaimana tertuang dalam Akta Pernyataan Keputusan Rapat No. 38 
tanggal 23 Desember 2008, dibuat oleh Notaris Theresiana Pusvita Dewi, SH yang telah telah memenuhi ketentuan kuorum jumlah pemegang saham yang hadir dan memberikan persetujuan sebagimana diputuskan dalam Penetapan Pengadilan Negeri wates No. 33/Pdt.P/2008/PN.WT tanggal 10 Desember 2008 dikeluarkan oleh Pengadilan Negeri wates.

Pemohon Pailit yang berkedudukan di Kulonprogo mengajukan permohonan pailit a quo secara sukarela ke Pengadilan Niaga pada Pengadilan Negeri Semarang, sesuai dengan Pasal 3 Ayat (1) juncto Ayat (5) Undang-Undang Nomor 37 Tahun 2004 Tentang Kepailitan dan Penundaan Kewajiban Pembayaran Utang juncto Pasal 2 Ayat (4) Keputusan Presiden Nomor 97 Tahun 1999 Tentang Pembentukan Pengadilan Niaga Pada Pengadilan Negeri Ujung Pandang, Pengadilan Negeri Medan, Pengadilan Negeri Surabaya, dan Pengadilan Negeri Semarang. Dikarenakan Pemohon Pailit tidak sanggup lagi membayar cicilan utang-utangnya kepada para Kreditor. Pemohon Pailit menggunakan Pasal 2 Ayat (1) Undang-Undang Nomor 37 Tahun 2004 Tentang Kepailitan dan Penundaan Kewajiban Pembayaran Utang sebagai dasar hukum permohonan pailitnya.

Putusan pailit nomor : 02/Pailit/2009/PN.Niaga.Smg menyebutkan bahwa Debitor memiliki beberapa Kreditor yang diakui dan memiliki utang yang telah jatuh tempo, yaitu Kreditor karywan dalam bentuk gaji dan uang pesangon dengan nilai nominal Rp. 2.531.596.211, Kreditor pribadi Iswanti dengan nilai nominal Rp. 939.648.688, Kreditor pribadi Wieke Ayati dengan nilai nominal Rp. 116.100.000, Kreditor Koperasi Unit Desa Sido Subur Sami Galuh, Koperasi Serba Usaha Surya Parama Arta Sentolo dan Koperasi Unit Desa Makmur Lendah dengan total nominal Rp. 63.130.200.

Cukup dengan memenuhi syarat yang termuat dalam Pasal 2 Ayat (1) Undang-Undang Nomor 37 Tahun 2004 Tentang Kepailitan dan Penundaan Kewajiban Pembayaran Utang, seorang Debitor, Kreditor atau Pihak ke tiga dapat mengajukan permohonan Pailit. Pemohon Pailit juga mendalilkan permohonannya dengan adanya pembuktian secara sederhana (sumir), berdasarkan Pasal 8 Ayat (4) Undang-Undang Nomor 37 Tahun 2004 Tentang Kepailitan dan Penundaan 
Kewajiban Pembayaran Utang. Untuk memperkuat alasan permohonan pailitnya, Pemohon Pailit mengajukan alat bukti surat, berupa dasar pendirian dan tempat kedudukan Perseroan Terbatas, penyelesaian masalah kepailitan telah disetujui melalui Rapat Umum Pemegang Saham (RUPS), dasar penetapan kuorum kehadiran dan pengambilan keputusan Rapat Umum Pemegang Saham (RUPS) sebesar 65\%, kondisi keuangan terakhir Perseroan Terbatas, baik aktiva maupun pasiva, identitas para Kreditor serta nilai hutang yang dimiliki. Alat bukti ini menerangkan bahwa Perseroan Terbatas memiliki lebih dari 2 orang Kreditor dan memiliki 1 Kreditor yang telah jatuh tempo, P-6, menerangkan Pemutusan Hubungan Kerja (PHK) terhadap karyawan Perseroan Terbatas, daftar karyawan serta besaran gaji dan uang pesangon yang menjadi hak para karyawan, dengan total nilai Rp. 2.513.596.211, dengan jatuh tempo 9 Januari 2009, kesepakatan pembayaran gaji dan uang pesangon karyawan, Perseroan Terbatas memiliki hutang kepada Iswanti sebesar Rp. 939.648.688, P-10, menerangkan nilai kewajiban yang disanggupi Perseroan Terbatas dan disetujui Iswati senilai Rp. 116.100.000, dengan jatuh tempo 31 Desember 2008, Perseroan Terbatas telah menerima dana dengan total Rp. 116.100.000, dari Wieke Ayati Hartana dan kesemuanya telah jatuh tempo, Perseroan Terbatas mempunyai pinjaman pada KUD Sido Subur, KSU MBT Surya Parama Artha, dan KUD Makmur Lendah dengan nilai pinjaman pokok sebesar Rp. 53.500.000, dan bunga sebesar 1,5\% per bulan dengan total pinjaman hingga saat ini sebesar Rp. 63.130.200, dan angsuran pertama telah jatuh tempo pada November 2008, Kurator yang ditunjuk oleh Pemohon telah terdaftar pada Departemen Hukum dan HAM Dirjen Hukum Umum, menerangkan Kurator tidak mempunyai benturan kepentingan dan tidak sedang menangani kepailitan lebih dari tiga perkara, Pemohon dengan status Perseroan Terbatas telah terdaftar pada Dinas Perindustrian Perdagangan Koperasi dan Pertambangan Kabupaten Kulon Progo, dan aset-aset yang dimiliki oleh Perseroan Terbatas. Selain alat bukti surat, Pemohon Pailit juga mengajukan satu orang saksi, yang telah disumpah sebelum diambil keterangannya. saksi bernama Suparyanto. Saksi merupakan karyawan sekaligus ketua serikat Pekerja PT. Uniqwood Karya, yang bernama serikat pekerja Manunggal Karya, yang 
menaungi 200 orang pekerja PT. Uniqwood Karya. Saksi menjelaskan bahwa telah dilakukan pemutusan hubungan kerja (PHK) melalui surat keputusan direksi PT. Uniqwood Karya tertanggal 24 desember 2009, dan dilanjutkan dengan kesepakatan bersama antara PT. Uniqwood Karya dengan karyawan PT. Uniqwood Karya pada tanggal 2 februari 2009, yang pada pokoknya disepakati bahwa PT. Uniqwood Karya akan melakukan pembayaran kewajiban kepada karyawan pada tanggal 9 Januari 2009 sebesar Rp. 2.513.596.211. Hingga waktu yang telah disepakati, pihak PT. Uniqwood Karya belum dapat melakukan kewajibannya kepada karyawan.

Pemohon Pailit juga meminta agar diangkat seorang Hakim Pengawas dan Kurator Kepailitan dalam perkaranya. Pemohon Pailit memohon kepada Majelis Hakim agar berkenan menunjuk Hakim Pengawas secara langsung dan menunjuk Andrian Kusumawardana. SH, Kurator Kepailitan No. C.HT.05.5-05 yang berkantor di YSA Law Office, Jalan Setiabudi VI Jakarta. Kurator yang dimohonkan oleh Pemohon Pailit tersebut telah menyampaikan surat pernyataan bahwa kurator bersikap Independen, tidak mempunyai benturan dengan Debitor atau Kreditor, dan tidak sedang menangani perkara kepailitan dan penundaan kewajiban pembayaran utang lebih dari tiga perkara. Pemohon Pailit mendalilkan hal tersebut berdasarkan Pasal 15 Ayat (1) juncto Ayat (3) juncto Pasal 16 Ayat (1) Undang-Undang Nomor 37 Tahun 2004 Tentang Kepailitan dan Penundaan Kewajiban Pembayaran Utang.

Dari hasil penelitian diatas, dapat ditemukan fakta bahwa pemohon pailt mendasarkan permohonannya atas: (1) Pasal 2 Ayat (1) Undang-Undang Nomor 37 Tahun 2004 Tentang Kepailitan dan Penundaan Kewajiban Pembayaran Utang, yang menjelaskan bahwa Debitor yang mempunyai dua atau lebih Kreditor dan tidak membayar lunas sedikitnya satu utang yang telah jatuh waktu dan dapat ditagih, dinyatakan pailit dengan putusan Pengadilan, baik atas permohonannya sendiri maupun atas permohonan satu atau lebih kreditornya. (2) Pasal 8 Ayat (4) Undang-Undang Nomor 37 Tahun 2004 Tentang Kepailitan dan Penundaan Kewajiban Pembayaran Utang, untuk membuktikan dalil-dalilnya terkait adanya fakta dan keadaan atau pembuktian secara sederhana (sumir). Hal tersebut 
didukung oleh adanya alat bukti surat P-1 sampai denga P-20 dan adanya satu orang saksi dibawah sumpah, yaitu saksi Suparyanto. (3) Pasal 3 Ayat (1) juncto Ayat (5) Undang-Undang Nomor 37 Tahun 2004 Tentang Kepailitan dan Penundaan Kewajiban Pembayaran Utang juncto Pasal 2 Ayat (4) Keputusan Presiden Nomor 97 Tahun 1999 Tentang Pembentukan Pengadilan Niaga Pada Pengadilan Negeri Ujung Pandang, Pengadilan Negeri Medan, Pengadilan Negeri Surabaya, dan Pengadilan Negeri Semarang. Pemohon Pailit mengajukan permohonan pailit terhadap dirinya sendiri secara sukarela ke Pengadilan Niaga pada Pengadilan Negeri Semarang. (4) Pasal 7 Ayat (1) Undang-Undang Nomor 37 Tahun 2004 Tentang Kepailitan dan Penundaan Kewajiban Pembayaran Utang, yang menjelaskan bahwa permohonan pailit tersebut harus diajukan oleh seorang advokat. (5) Pasal 104 Ayat (1) Undang-Undang Nomor 40 Tanun 2007 Tentang Perseroan, dimana Direksi tidak dapat mengajukan permohonan pailit tanpa persetujuan Rapat Umum Pemegang Saham (RUPS). (6) Pasal 15 Ayat (1) juncto Ayat (3) juncto Pasal 16 Ayat (1) Undang-Undang Nomor 37 Tahun 2004 Tentang Kepailitan dan Penundaan Kewajiban Pembayaran Utang terakit pengangkatan seorang Hakim Pengawas dan Kurator Kepailitan.

\section{Pertimbangan Yang Diberikan Oleh Majelis Hakim Dalam Putusan Pailit Nomor : 02/Pailit/2009/PN.Niaga.Smg Telah Sesuai Dengan Undang-Undang Nomor 37 Tahun 2004 Tentang Kepailitan dan Penundaan Kewajiban Pembayaran Utang}

Atas permohonan PT. Uniqwood Karya, dalam putusannya majelis hakim memberikan pertimbangan bahwa Pemohon Pailit mengajukan permohonan pailit untuk dirinya sendiri dengan dalil-dalil bahwa selaku badan hukum yang berbentuk Perseroan Terbatas, Pemohon Pailit sudah tidak dapat membayar lunas gaji dan uang pesangon para karyawan yang telah jatuh tempo. Selain itu, karena keadaan Pemohon Pailit sedang mengalami kesulitan pembayaran utangnya, Pemohon Pailit juga tidak dapat membayar lunas utangnya yang telah jatuh tempo kepada beberapa Kreditornya. Dengan ditemukannya fakta dan dan keadaan tidak dapat membayar utangnya tersebut dapat dibuktikan secara sederhana, maka 
syarat-syarat untuk dinyatakan pailit bagi Pemohon Pailit yang ditentukan dalam Undang-Undang Nomor 37 Tahun 2004 Tentang Kepailitan dan Penundaan Kewajiban Pembayaran Utang telah terpenuhi dengan di ajukan bukti surat bertanda P-1 sampai dengan P-20 dan juga adanya seorang saksi dibawah sumpah, yaitu saksi Suparyanto.

Majelis Hakim yang memeriksa dan mengadili perkara permohonan pailit Pemohon memberikan pendapat bahwa prinsip dasar hukum kepailitan sebenarnya mengatur bagaimana halnya jika seorang Debitor tidak dapat membayar utang-utangnya, serta bagaimana pertanggungjawaban Debitor tersebut dalam kewenangannya terhadap harta kekayaan yang masih atau akan dimilikinya. Selain itu, maksud kepailitan pada dasarnya membagi-bagi hasil penjualan semua harta kekayaan Debitor secara seimbang kepada semua Kreditor, maka lembaga kepailitan hanya akan ada apabila Debitor memiliki lebih dari seorang Kreditor. Keberadaan lebih dari seorang Kreditor ini dikenal dengan prinsip concursus creditorium. Debitor hanya dapat dinyatakan pailit, jika memiliki lebih dari seorang kreditor. Dengan adanya prinsip hukum yang demikian, maka dalam Undang-Undang Nomor 37 Tahun 2004 Tentang Kepailitan dan Penundaan Kewajiban Pembayaran Utang diharapkan ada suatu mekanisme hukum yang jelas dan dapat dijamin kepentingan hukum para Kreditor, khususnya tentang tata cara dan hak Kreditor untuk memperoleh kembali pembayaran piutangnya dari seorang Debitor yang dinyatakan pailit.

Mempertimbangkan keadaan dimana permohonan pailit ini diajukan oleh dan atau untuk Pemohon Pailit sendiri, yaitu PT. Uniqwood Karya, Suatu Perseroan Terbatas yang didirikan menurut dan berdasar hukum negara Republik Indonesia, dengan Akta Pendirian No. 33 tanggal 11 agustus 1990, dibuat oleh Silvia Veronika, SH., Notaris di Yogyakarta, yang telah mendapat status Badan Hukum dengan pengesahan Menteri Hukum dan perundang-undangan Nomor C.2-1144.ht.0I.0I.Th.1991 tanggal 25 april 1991, berkedudukan di Gunung Godang Margosari 65 Pengasih, Kulonprogo. Dalam kualitas dan kedudukan hukumnya yang demikian, maka untuk memutuskan perkara ini pertama-tama perlu dipertimbangkan subjek hukum Pemohon Pailit telah tepat dan benar 
menurut hukum untuk bertindak mengajukan permohonan pailit atas dirinya sendiri tersebut.

Subjek hukum Pemohon Pailit harus dikaji dengan menelaah syarat formal subjek hukum Pemohon Pailit berdasarkan ketentuan dalam Undang-Undang Nomor 37 Tahun 2004 Tentang Kepailitan dan Penundaan Kewajiban Pembayaran Utang dalam relevansinya dengan ketentuan-ketentuan dalam Undang-Undang Nomor 1 Tahun 1995 Tentang Perseroan Terbatas sebagaimana telah diubah dengan Undang-Undang Nomor 40 Tahun 2007 Tentang Perseroan Terbatas. Permohonan pailit ini diajukan oleh Pemohon Pailit untuk dirinya sendiri, maka pihak yang berkedudukan sebagai Pemohon Pailit harus orang yang benar-benar memiliki kedudukan dan kapasisitas yang tepat menurut hukum. Keliru dan salah bertindak sebagai Pemohon Pailit mengakibatkan permohonan pailit mengandung cacat formil. Perkara kepailitan sesungguhnya harus diupayakan untuk mengatasi keengganan Debitor untuk memenuhi kewajibannya, dengan cara menentukan tingkatan Kreditor serta prioritas pembayaran terhadap piutang-piutangnya, dengan cara mengadakan tindakan-tindakan untuk mencegah Debitor menyingkirkan harta kekayaannya, dengan mengadakan pengaturan tentang pemberesan terhadap harta kekayaan hingga rehabilitasi Debitor. Oleh karena itu, didalamnya juga harus terdapat suatu jaminan agar Debitor diperlakukan secara tidak semena-mena karena sesungguhnya lembaga kepailitan merupakan suatu sistem yang mengatur bagaimanakah hukum harus bertindak manakalah seorang Debitor tidak dapat membayar hutang-hutangnya, dan bagaimanakah pertanggungjawaban Debitor tersebut, dalam hubungannya dengan harta kekayaan yang masih atau akan dimilikinya.

Badan hukum sebagai persoon dalam hukum acara perdata juga adalah sebagai subjek hukum. Artinya badan hukum itu juga dapat menjadi pihak yang berperkara. Dalam Hukum Acara Perdata, badan hukum selalu diwakili, dan yang mewakilinya adalah organ yang berhak menurut undang-undang atau anggaran dasarnya (statuten) (Pasal 1655 KUH Perdata). Majelis hakim memberikan contoh, didalam perseroan, direksi merupakan organ Perseroan Terbatas yang menjadi wakil badan hukum itu sendiri. Badan hukum Perseroan Terbatas dapat 
mengajukan dan atau diajukan sebagai pihak dalam permohonan pailit sesuai dengan tempat kedudukan hukumnya sebagaimana ditentukan dalam anggaran dasarnya.

Undang-Undang Nomor 37 Tahun 2004 Tentang Kepailitan dan Penundaan Kewajiban Pembayaran Utang mengatur bahwa permohonan pailit tersebut dapat juga diajukan di tempat kedudukan hukum terakhirnya, atau di tempat Perseroan Terbatas tersebut menjalankan profesi atau aktifitas usahanya (Pasal 3 UndangUndang Nomor 37 Tahun 2004 Tentang Kepailitan dan Penundaan Kewajiban Pembayaran Utang).

Setelah memperhatikan surat-surat bukti Pemohon Pailit terutama bukti P-1, P-2 dan P-3, maka telah dapat dibuktikan kebenaran kualitas subjek Hukum Pemohon Pailit dalam relevansinya dengan kewenangan Pengadilan Niaga pada Pengadilan Negeri Semarang untuk memeriksa dan mengadili perkara ini. Kualitas Pemohon Pailit yang dipandang telah dapat dan benar berdasarkan pertimbangan hukum, sebagai berikut: (1) Bahwa dalam Hukum Acara Perdata Indonesia telah ditentukan suatu badan hukum berhak bertindak sebagai Penggugat atau Tergugat dalam suatu perkara perdata. (Pasal 2 Ayat (2) $R v$ ). Akan tetapi perlu dimengerti, bahwa dalam hukum acara perdata terdapat dua pengertian mengenai apa yang disebut process partij yaitu materieele partij, yaitu orang yang hak nya diperkarakan, dan formeele partij yaitu orang yang harus bertindak sebagai wakil dalam suatu perkara. Dalam badan hukum organ yang mewakilinya adalah adalah formeele partij. Jadi sudah terang kepribadian hukum (rechtspersoonlijkheid) dalam badan hukum itu, hal ini dalam hukum acara perdata sudah merupakan suatu pengertian (begrip) yang sudah ada sebagaimana majelis hakim melakukan pengutipan dari buku karangan Chaidir Asli halaman 178. Hal tersebut juga dijelaskan oleh M. Yahya Harahap terkait para pihak dalam suatu gugatan perdata di dalam bukunya yang berjudul Hukum Acara Perdata (Harahap 2011:111-136). (2) Bahwa dalam kedudukannya sebagai subyek hukum yang mandiri, maka keberadaan Perseroan Terbatas, lain dengan suatu firma, karena kedudukannya tersebut tidak bergantung dari keberadaan para pemegang sahamnya, para anggota direksi dan dewan komisaris. Oleh karena itu pergantian 
organ Perseroan Terbatas tersebut tidak akan memperngaruhi keberadaan Perseroan Terbatas selaku "persona standi in judicio" (subyek hukum yang cakap dan dapat bertindak dalam hukum). (3) Bahwa memperhatikan bukti Penggugat tertanda P-1 s/d P-3, ternyata Pemohon Pailit telah dapat membuktikan tentang dasar Pendirian dan Permohonan Pailit telah dapat membuktikan tentang dasar Pendirian dan tempat kedudukan Perseroannya. Disamping itu, penyelesaian masalah utangnya melalui lemabaga kepailitan dalam perkara ini, telah disetujui Rapat Umum pemegang Saham (RUPS) (Pasal 104 Ayat (1) Undang-Undang Nomor 40 Tahun 2007 Tentang Perseroan Terbatas). Hal ini, perlu dipertimbangkan karena suatu perbuatan perdata suatu badan hukum Perseroan Terbatas, harus berdasarkan undang-undang dan atau dengan undang-undang (de gesloten syateem van rechtspersonen). Oleh karena itulah dalam suatu Perseroan Terbatas ada pengurus Perseroan Terbatas yang lazim disebut "Direksi", merupakan salah satu organ Perseroan Terbatas yang harus ada dengan tugas melakukan kepengaurusan serta mewakili Perseroan Terbatas, baik didalam maupun diluar Pengadilan. Menurut teori organisme dari Otto Von Gierke seperti dikutip Suyling, pengurus adalah organ atau alat perlengkapan dari badan hukum, sehingga pengurus adalah personifikasi dari badan hukum itu sendiri. Menurut Paul Scholten dan Brengstein, pengurus mewakili badan hukum. Berdasarkan analog pendapat Hierke dan Paul Scholten meupun Brengstein tersebut, Direksi bertindak mewakili perseroan sebagai badan hukum. Hakikat dari perwakilan, bahwa seorang melakukan sesuatu perbuatan hukum untuk kepentingan orang lain atas tanggung jawab dari orang itu (Usman 2004:146). (4) Bahwa sesuai ketentuan Pasal 92 Undang-Undang Nomor 40 Tahun 2007 Tentang Perseroan Terbatas menyatakan "kepengurusan perseroan dilakukan oleh perseroan". Kemudian penjelasan Pasal tersebut menegaskan "Ketentuan ini menugaskan Direksi untuk mengurus Perseroan Terbatas yang antara lain meliputi pengurusan sehari-hari daro perseroan". Pasal 1 Ayat (5) Undang-Undang Nomor 40 Tahun 2007 Tentang Perseroan Terbatas dinyatakan "Direksi adalah organ Perseroan Terbatas yang bertanggung jawab penuh atas pengurusan perseroan untuk lepentingan dan tujuan perseroan serta mewakili perseroan baik didalam maupun 
di luar Pengadilan sesuai dengan ketentuan anggaran Dasar". (5) Bahwa berdasarkan pertimbangan hukum tersebut diatas, maka kalaulah dalam permohonan pailitnya Pemohon Pailit telah meyebutkan status/kualitasnya sebagai suatu badan hukum perseroan terbtas in casu PT. Uniqwood Karya, yaitu suatu badan yang ada karena hukum, dan memang diperlukan keberadaannya sehingga disebut legal entity atau rechtspersoon, artinya orang buatan yang diciptakan oleh hukum. Oleh karena itu dapat bertindak menurut hukum dan memiliki kewenangan - legitimata persona standi in juditio sehingga tindakannya mengajukan permohonan pailit ini telah tepat dan benar berdasarkan hukum.

Dalam substansi (materi) permohonan pailit, bahwa berdasarkan ketentuan Pasal 2 Ayat (1) Undang-Undang Nomor 37 Tahun 2004 Tentang Kepailitan dan Penundaan Kewajiban Pembayaran Utang telah diatur syarat-syarat untuk sahnya Debitor dapat dinyatakan pailit adalah sebagai berikut: (1) Debitor mempunyai dua atau lebih Kreditor, dan (2) Tidak dapat membayar lunas setidaknya satu utang yang telah jatuh waktu dan dapat ditagih.

Disamping itu untuk dapat dinyatakan pailit, bersangkut paut dengan acara pemeriksaan permohonan pailit yaitu dengan berlandasan pemeriksaan cepat (speedy trial) sebagaimana dengan tegas diatur Pasal 8 Ayat (4) Undang-Undang Nomor 37 Tahun 2004 Tentang Kepailitan dan Penundaan Kewajiban Pembayaran Utang yang menyatakan "Permohonan pernyataan pailit harus dikabulkan apabila terdapat fakta atau keadaan yang terbukti secara sederhana bahwa persyaratan untuk dinyatakan pailit sebagaimana dikasud dalam Pasal 2 Ayat (2) telah dipenuhi”. Diharapkan dalam pemeriksaan permohonan pailit seyogyanya harus bebas dari unsur sengketa yang rumit, karena jika terdapat sengketa yang tidak dapat dibuktikan adanya suatu fakta atau keadaan utang yang terbukti secara sederhana, maka sesungguhnya Pengadilan Niaga tidak berwenang untuk mengadilinya. Hal tersebut dikarnakan dalam suatu fakta atau keadaan utang yang tidak sederhana, tidak dapat diputuskan dengan menggunakan sarana lembaga hukum kepailitan, akan tetapi harus diadili melalui gugatan ke Pengadilan Negeri di wilayah hukum para pihak yang bersengketa. 
Dalam permohonannya, Pemohon pailit menyatakan bahwa Pemohon Pailit tidak dapat membayar gaji maupun pesangaon karyawannya dan juga membayar kembali utangnya kepada para kreditornya tersebut. Di persidangan pada pokoknya Pemohon Pailit juga menerangkan hal tersebut semata-mata murni karena adanya masalah bisnis karena sepinya permintaan (ordir) dari produknya dan kesalahan management serta tidak ada unsur pedanya. Dengan demikian, Majelis Hakim yang memeriksa dan mengadili perkara berpandangan bahwa esensi permohonan Pailit trsebut diatas tidak mengindikasikan adanya suatu perkara atau sengketa dalam permohonan pailit yang sedang diperiksa saat ini, akan tetapi permohonan tersebut pada dasarnya semata-mata didasarkan pada suatu fakta dan keadaan tidak dibayarnya gaji dan pesangon karyawannya dan kewajiban Pemohon Pailit kepada para kreditor, yang akhirnya melahirkan adanya utang telah jatuh tempo dan dapat ditagih untuk dapat dijadikan sebagai dasar dalam mengajukan permohonan pailit.

Agar lembaga kepailitan tidak disalahgunakan oleh pihak yang tidak beritikat baik, untuk kepentingan dirinya semata, dan atau pun juga untuk melindungi kepentingan Kreditor lainnya, maka Majelis Hakim tetap memandang perlu untuk mempertimbangkan bukti-bukti yang diajukannya, terutama untuk membuktikan apakah keseluruhan syarat-syarat untuk dijatuhkannya putusan pailit terhadap diri Pemohon Pailit tersebut telah sesuai dengan berjalannya hukum, kebenaran dan keadilan. Dalam Pasal 1925 KUH Perdata telah diatur siapa saja yang berwenang untuk memberi pengakuan, yaitu dilakukan oleh diri sendiri atau orang prinsipal sendiri atau oleh orang yang diberikan kuasa oleh orang lain bagi kepentingan prisipal dengan suatu suart kuasa khusus dan pada prinsipnya dalam Hukum Acara Perdata yang berlaku di Indonesia sebagimana diatur dalam 174-176 HIR (bandingkan dengan Pasal 311 RBg-313RBg) dan juga Pasal 1923 -1928 KUH Perdata mengatur bahwa pengakuan dari salah satu pihak kepada pihak lain dalam pemeriksaan di persidangan yang diberikan secara sukarela harus dianggap selamanya, karenanya hakim terikat dan harus menerimanya. Suatu pengakuan yang diberikan di persidangan pengadilan merupakan suatu buktiyang bersifat sempurna yang mengikat dan menentukan 
(bindende dan beslissende). Pengakuan Pemohon Pailit tentang adanya utang yang belum dapat dibayarkan kembali ketika sudah jatuh tempo tersebut, ternyata berseuaian dengan dalil-dalil permohonan Pemohon Pailit tersebut dan bukti-bukti yang diajukan di persidangan (Bukti P-4 s/d P-16), maka pengakuan Pemohon Pailit itu bersifat mutlak karena diajukan sesuai dengan yang sebenarnya dan didasarkan dengan alasan yang kuat (met redenen omkleed), maka menurut hukum haruslah dipercaya.

Pengertian utang dalam Undang-Undang Nomor 37 Tahun 2004 Tentang Kepailitan dan Penundaan Kewajiban Pembayaran Utang bukan lah pengertian utang dalam arti sempit dan terbatas hanya pada perikatan pinjam meminjam uang, akan tetapi pengertian utang meliputi setiap kewajiban yang dinyatakan atau dapat dinyatakan dalm jumlah uang baik dalam mata uang Indonesia maupun mata uang asing, baik secara langsung maupun yang akan timbul dikemudia hari atau kontijen, yang timbul karena perjanjian atau undang-undang dan yang wajib dipenuhi oleh Debitor dan bila tidak dipenuhi memberi hak pada Kreditor untuk mendapatkan pemenuhannya dari harta kekayaan Debitor (Pasal 1 Angka 6 Undang-Undang Nomor 37 Tahun 2004 Tentang Kepailitan dan Penundaan Kewajiban Pembayaran Utang). Berdasarkan bukti surat P-4 yang menerangkan kondisi keuangan Pemohon Pailit menakalah dihubungkan dengan bukti P-5 s/d P-16 dan seorang saksi yang bernama Suparyanto yang telah diajukan Pemohon Pailit, telah dapat dibuktikan bahwa Pemohon Pailit memiliki kewajiban untuk membayar gaji dan pesangon karyawan yang telah diputuskan hubungan kerjanya maupun utang Pemohon Pailit kepada beberapa kreditor yang sudah jatuh tempo dan harus dibayarkan. Semua kewajiban atau liability tersebut dapat diniai dengan sejumlah uang dan wajib dipenuhi oleh Pemohon Pailit. Dengan demikian, telah terbukti bahwa Pemohon Pailit sudah memenuhi syarat untuk dikategorikan sebagai seorang Debitor sebagaimana dirumuskan dalam Pasal 1 Angka 4 Undang-Undang Nomor 37 Tahun 2004 Tentang Kepailitan dan Penundaan Kewajiban Pembayaran Utang yaitu : "Debitor adalah orang yang memiliki utang karena perjanjian atau undang-undang yang pelunasannya dapat ditagih di muka pengadilan”. Dengan demikian, adanya kewajiban-kewajiban untuk membayarkan 
sejumlah tang yang telah jatuh tempo dan dapat ditagih tersebut, telah terbukti dan telah nyata Pemohon Pailit memiliki lebih dari dua orang Kreditor.

Berdasarkan hal-hal tersebut diatas, telah didapati adanya prima facie kepailitan dalam pemohonan ini yaitu dapat dibuktikan adanya suatu fakta atau keadaan yang terbukti secara sederhana bahwa persyaratan untuk dinyatakan pailit sebagaimana dimaksud dalam Pasal 2 Ayat (1) Undang-Undang Nomor 37 Tahun 2004 Tentang Kepailitan dan Penundaan Kewajiban Pembayaran Utang juncto Pasal 8 Ayat (4) Undang-Undang Nomor 37 Tahun 2004 Tentang Kepailitan dan Penundaan Kewajiban Pembayaran Utang telah terpenuhi. Oleh karena itu, permohonan pailit dari Pemohon Pailit yang memohon agar Pemohon Pailit dinyatakan pailit dengan segala akibat hukumnya adalah layak dan patut untuk dikabulkan.

Pasal 15 Ayat (1) Undang-Undang Nomor 37 Tahun 2004 Tentang Kepailitan dan Penundaan Kewajiban Pembayaran Utang telah diatur bahwa dalam putusan pernyataan pailit harus diangkat seorang Kurator untuk mengurus dan membereskan budel pailit. Pemohon Pailit sudah menentukan dan memilih sendiri agar mengangkat Andrian Kusumawardana. SH, Kurator Kepailitan No. C.HT.05.5-05 yang berkantor di YSA Law Office, Jalan Setiabudi VI Jakarta, sebagai Kurator dalam perkara kepailitan ini. Berdasarkan bukti P-17 dan P-18 yang bersangkutan ternyata tidak berkepentingan dengan diajukannya perkara ini dan tidak memiliki konflik kepentingan, sehingga diharapkan dapat bersikap independen serta tidak sedang menangani 3 (tiga) perkara kepailitan yang sedang berlangsung, maka yang bersangkutan patut diangkat menjadi Kurator dalam kepailitan.

Guna mengawasi jalannya pengurusan dan pemberesan dari budel pailit tersebut perlu ditunjuk seorang Hakim Pengawas dari salah seorang Hakim Niaga Pengadilan Niaga pada Pengadilan Negeri Semarang. Didalam putusan Drs. Amin Sembiring, SH., MH, diangkat dan ditunjuk sebagai Hakim Niaga Pengadilan Niaga pada Pengadilan Negeri Semarang untuk menjadi Hakim Pengawas dalam perkara kepailitan PT. Uniqwood Karya. 
Berdasarkan keseluruhan pertimbangan hukum yang diberikan oleh Majelis Hakim yang memeriksa dan mengadili perkara, maka permohonan pailit patut dan layak untuk dikabulkan seluruhnya. Hal ini mengakibatkan PT. Uniqwood Karya dinyatakan pailit dengan segala akibat hukumnya dan biaya permohonan pailit dibebankan kepada Pemohon Pailit untuk seluruhnya.

Dasar pertimbangan hukum Majelis Hakim dalam memeriksa dan mengadili perkara tersebut, yaitu: (1) Pasal 2 Ayat (1) Undang-Undang Nomor 37 Tahun 2004 Tentang Kepailitan dan Penundaan Kewajiban Pembayaran Utang, yang menjelaskan bahwa Debitor yang mempunyai dua atau lebih Kreditor dan tidak membayar lunas sedikitnya satu utang yang telah jatuh waktu dan dapat ditagih, dinyatakan pailit dengan putusan Pengadilan, baik atas permohonannya sendiri maupun atas permohonan satu atau lebih kreditornya. (2) Pasal 8 Ayat (4) Undang-Undang Nomor 37 Tahun 2004 Tentang Kepailitan dan Penundaan Kewajiban Pembayaran Utang, untuk membuktikan dalil-dalilnya terkait adanya fakta dan keadaan atau pembuktian secara sederhana (sumir). Hal tersebut didukung oleh adanya alat bukti surat P-1 sampai denga P-20 dan adanya satu orang saksi dibawah sumpah, yaitu saksi Suparyanto. (3) Pasal 3 Ayat (1) juncto Ayat (5) Undang-Undang Nomor 37 Tahun 2004 Tentang Kepailitan dan Penundaan Kewajiban Pembayaran Utang juncto Pasal 2 Ayat (4) Keputusan Presiden Nomor 97 Tahun 1999 Tentang Pembentukan Pengadilan Niaga Pada Pengadilan Negeri Ujung Pandang, Pengadilan Negeri Medan, Pengadilan Negeri Surabaya, dan Pengadilan Negeri Semarang. Pemohon Pailit mengajukan permohonan pailit terhadap dirinya sendiri secara sukarela ke Pengadilan Niaga pada Pengadilan Negeri Semarang. (4) Pasal 7 Ayat (1) Undang-Undang Nomor 37 Tahun 2004 Tentang Kepailitan dan Penundaan Kewajiban Pembayaran Utang, yang menjelaskan bahwa permohonan pailit tersebut harus diajukan oleh seorang advokat. (5) Pasal 15 Ayat (1) juncto Ayat (3) juncto Pasal 16 Ayat (1) UndangUndang Nomor 37 Tahun 2004 Tentang Kepailitan dan Penundaan Kewajiban Pembayaran Utang terakit pengangkatan seorang Hakim Pengawas dan Kurator Kepailitan. (6) Pasal 104 Ayat (1) Undang-Undang Nomor 40 Tanun 2007 Tentang Perseroan, dimana Direksi tidak dapat mengajukan permohonan pailit 
tanpa persetujuan Rapat Umum Pemegang Saham (RUPS). (7) Pasal 92 juncto Pasal 1 Angka 5 Undang-Undang Nomor 40 Tahun 2007 Tentang Perseroan Terbatas yang menyatakan bahwa pengurusan Perseroan Terbatas dilakukan oleh Direksi. (8) Pasal 1655 KUH Perdata yang menjelaskan Para pengurus badan hukum, bila tidak ditentukan lain dalam akta pendiriannya, dalam surat perjanjian atau dalam reglemen berkuasa untuk bertindak demi dan atas nama badan hukum itu, untuk mengikatkan badan hukum itu kepada Pihak ke tiga atau sebaliknya, dan untuk bertindak dalam sidang Pengadilan baik sebagai penggugat maupun sebagai tergugat. (9) Pasal 2 Ayat (2) Reglement op de Rechtsvordering terkait badan hukum berhak bertindak sebagai Penggugat atau Tergugat dalam suatu perkara perdata, yaitu orang yang harus bertindak sebagai wakil dalam suatu perkara (formeele partij). (10) PT. Uniqwood Karya merupakan suatu badan yang ada karena hukum, dan memang diperlukan keberadaannya sehingga disebut legal entity atau rechtspersoon, artinya orang buatan yang diciptakan oleh hukum. Oleh karena itu dapat bertindak menurut hukum dan memiliki kewenangan - legitimata persona standi in juditio sehingga tindakannya mengajukan permohonan pailit ini telah tepat dan benar berdasarkan hukum. (11) Pasal 1925 KUH Perdata terkait Pengakuan yang diberikan di hadapan Hakim, merupakan suatu bukti yang sempurna terhadap orang yang telah memberikannya, baik sendiri maupun dengan perantaraan seseorang yang diberi kuasa khusus untuk itu.

\section{SIMPULAN}

Dasar permohonan pailit yang diajukan oleh Pemohon Pailit dalam putusan pailit nomor : 02/Pailit/2009/PN.Niaga.Smg tidak bertentangan dengan UndangUndang Nomor 37 Tahun 2004 Tentang Kepailitan dan Penundaan Kewajiban Pembayaran Utang mengingat tidak adanya batasan antara permohonanan pailit terhadap dirinya sendiri dengan permohonan yang diajukan oleh Kreditor dan Pihak ke tiga. Dengan memenuhi syarat yang ada pada Pasal 2 Ayat (1) dan Pasal 8 Ayat (4) Undang-Undang Nomor 37 Tahun 2004 Tentang Kepailitan dan Penundaan Kewajiban Pembayaran Utang, maka permohonan pailit dapat dikabulkan. 
Pertimbangan yang diberikan oleh majelis hakim dalam putusan pailit nomor : 02/Pailit/2009/PN.Niaga.Smg tidak bertentangan dengan Undang-Undang Nomor 37 Tahun 2004 Tentang Kepailitan dan Penundaan Kewajiban Pembayaran Utang mengingat tidak adanya batasan antara permohonanan pailit terhadap dirinya sendiri dengan permohonan yang diajukan oleh Kreditor dan Pihak ke tiga. Dengan memenuhi syarat yang ada pada Pasal 2 Ayat (1) dan Pasal 8 Ayat (4) Undang-Undang Nomor 37 Tahun 2004 Tentang Kepailitan dan Penundaan Kewajiban Pembayaran Utang, maka permohonan pailit dapat dikabulkan.

\section{DAFTAR PUSTAKA}

\section{Buku}

Darmawi, Herman. 2010. Manajemen Resiko. Jakarta: Bumi Aksara.

Fuady, Munir. 2001. Pengantar Hukum Bisnis. Bandung: Citra Aditya Bakti.

Harahap, M. Yahyah. 2011. Hukum Acara Perdata Tentang Gugatan, Persidangan, Penyitaan, Pembuktian, dan Putusan Pengadilan. Jakarta: Sinar Grafika.

Hartini, Rahayu. 2007. Hukum Kepailitan. Malang: UMM Pers.

Hartono, Sri Rejeki. 2001. Hukum Asuransi dan Perusahaan Asuransi. Jakarta: Sinar Grafika.

Hernoko, Agus Yhuda. 2011. Hukum Perjanjian Asas Proporsionalitas Dalam Kontrak Komersial. Jakarta: Kencana.

Husni, Lalu. 2010. Pengantar Hukum Ketenagakerjaan Indonesia Edisi Revisi. Jakarta: Rajawali Pers.

Ibrahim, Johnny. 2008. Teori dan Metodologi Penelitian Hukum Normatif. Malang: Bayumedia Publishing.

Irsan Nasarudin M, dkk. 2003. Aspek Hukum Pasar Modal Indonesia. Jakarta: Kencana.

Marzuki, Peter Muhammad. 2006. Penelitian Hukum. Jakarta: Kencana. 
Moleong, Lexy J. 2013. Metodologi Penelitian Kualitatif Edisi Revisi. Bandung: Remaja Rosdakarya Offset.

Rahardjo, Satjipto. 2006. Pengantar Penelitian Hukum. Jakarta: UI Press.

Rochmat, Soemitro. 1993. Hukum Perseroan Terbatas, Yayasan dan Wakaf. Bandung: Eresco.

Sastrawidjaja, H. Man S. 2006. Hukum Kepailitan Dan Penundaan Kewajiban Pembayaran Utang. Bandung: Alumni.

Setiawan, R. 2000. Pokok-Pokok Hukum Perikatan. Bandung: Percetakan Ekonomi.

Shubhan, M. Hadi. 2009. Hukum Kepailitan: Prinsip, Norma dan praktek di Peradilan. Jakarta: kencana.

Sinaga, Syamsudin M. 2012. Hukum Kepailitan Indonesia. Jakarta: Indonesia.

Subekti dan Tjitrosudibio. 2008. Kitab Undang-Undang Hukum Perdata. Jakarta: Malta Printindo.

Sudarsono. 2009. Kamus Hukum. Jakarta: Rineka Cipta.

Suharnoko dan Hartati, Enda. 2008. Dotrin Subrogasi, Novasi dan Cessie. Jakarta: Kencana.

Sunggono, Bambang. 2011. Metodologi Penelitian Hukum. Jakarta: Rajawali Pers.

Supramono, Gatot. 2007. Hukum Perseroan Terbatas. Jakarta: Djambatan.

Victor MS dan Hendri S. 1994. Pengantar Hukum Kepailitan Di Indonesia. Jakarta: Rineka Cipta.

Yani, Ahmad dan Widjaja, Gunawan. 2000. Seri Hukum Bisnis Kepailitan. Jakarta: Raja Grafindo Persada.

\section{Peraturan Perundang-Undangan}

Keputusan Presiden Nomor 97 Tahun 1999 Pembentukan Pengadilan Niaga Pada Pengadilan Negeri Ujung Pandang, Pengadilan Negeri Medan, Pengadilan Negeri Surabaya, Dan Pengadilan Negeri Semarang.

Undang-Undang Nomor 13 Tahun 2003 Tentang Ketenagakerjaan.

Undang-Undang Nomor 37 Tahun 2004 Tentang Kepailitan dan Penundaan Kewajiban Pembayaran Utang. 
Undang-Undang Nomor 4 Tahun 1998 Tentang Penetapan Peraturan Pemerintah Pengganti Undang-Undang Nomor 1 Tahun 1998 Tentang Perubahan Atas Undang-Undang Tentang Kepailitan Menjadi Undang-Undang.

Undang-Undang Nomor 40 Tahun 2007 Tentang Perseroan Terbatas. 
